Journal of the Textile Institute Proceedings and Abstracts

\title{
LANCASHIRE SECTION: Meeting at Manchester, 17th December, 1920. Mr. W. Greenwood, M.P. in the Chair. MANAGEMENT PROBLEMS
}

\section{F. Arrowsmith}

To cite this article: F. Arrowsmith (1921) LANCASHIRE SECTION: Meeting at Manchester, 17th December, 1920. Mr. W. Greenwood, M.P. in the Chair. MANAGEMENT PROBLEMS, Journal of the Textile Institute Proceedings and Abstracts, 12:2, 39-40, DOI: $10.1080 / 00405002108630991$

To link to this article: http://dx.doi.org/10.1080/00405002108630991

曲 Published online: 25 Nov 2008.

Submit your article to this journal $\widetilde{ }$

Џll Article views: 3

View related articles 


\section{PROCEEDINGS OF THE INSTITUTE}

\section{LANCASHIRE SECTION}

Meeting at Manchester, 17th December, 1920.

Mr. W. Greenwood, M.P. in the Chair.

\section{MANAGEMENT PROBLEMS}

By F. Arrowsmith.

The speaker pointed out that this was an old subject, but conditions and circumstances, and the whole attitude, outlook, and education of the people were changing so rapidly that the problem could be considered as quite fresh. He proposed to treat the matter from the directorial or head-management point of view, quoting from "Factory Management Waste," by Whiteford, that management consisted of " $10 \%$ technique and $90 \%$ psychologic" and that "Responsibility starts at the top, and managers are directly successful in direct ratio to the extent to which responsibility can be apportioned to the various members of the organisation." He also quoted "Scientific Management," by A. D. Denning, as the best book on the subject he had seen. He agreed with the author that the function of management was the "quite distinct profession of managing men," and that a "Factory main problem is human nature." His own definition of the management problem was: How to get the greatest value of output per operative at the least cost, with the greatest comfort and the highest pay to the worker.

In order to solve this problem (Mr. Arrowsmith continued) it is necessary to understand both the raw material and the human element involved. It has been the fashion, of late, to state that the working man makes no mistake, has not had opportunity, and has been badly used; and on the other hand to state that he is bigoted, selfish, and undisciplined. These assertions-and acting upon them-are calculated to create trouble. It is probable that the assistant managers, foremen, or overlookers, understand the psychology of the working men and women better than the average managing-director understands it. Therefore, it should not occasion surprise, and it is a fact, that instructions from the head of a concern are modified at the time they come to be issued at the various stages berore they actually become operative. We need still better education for our workers, though it is fortunate that they are so well advanced in this respect compared with certain other countries. We need only look at Russia to-day to realise what may happen in the case of an uneducated people at time of stress and trial. In our own country, we have, $\mathrm{cf}$ late, seen leader after leader of workers deposed, particularly in the case of the workers in the South Wales coal-field. The workers have not yet realised that there is work to be done, and that the more there is done the more there is to do.' Put quite bluntly, this means that the workers generally are perhaps half educated and probably only quarter developed. The fault cannot all be attributed to the workers, whose education is not yet what it should be. At the present time there is a terrific outery for national economy, hut if we economise at the sacrifice of educational progress we are not likely to benefit as a nation. If a business concern is struggling against adverse circumstances and going to the wall, it cannot be saved by economies and cutting down expenses, unless it is hopelessly mismanaged. The remedy is to be found in enterprising and judicious expenditure. If the recent economy "stunt" is intended to thwart the operations of the Fisher Education Act, it is ill-directed to that extent at any rate. It is through education and develpoment that we may secure both work and out-turn. Some people suggest that if all are well educated there will be no labour for the lowest class of work-in other words, nobody to sweep the floors. The real fact is that a lct of work of this description will be accomplished in a scientific manner. More than half of the unrest of to-day is not the result of Labour's dislike for Capital, or of distrust of employers and managers, but of jealousy among employees themselves. The improvement in the education of the workers can be stimulated by the Whitley Councils, extended education under the Fisher Scheme, and by efficient welfare work. Bullying and driving in industry, if they ever really existed, are certainly now of the past. Even working for merely something to eat is not now tolerated. I believe that in course of time the workers will have to have representation on our management boards, and here again the movement in education is of vitel concern to all.

\section{Discussion.}

Mr. H. P. Greg said that if we wanted to understand the workpeople in industry we must understand ourselves. We should realise that if we were to have really useful work it must be creative and not merely critical. It had been urged recently that the manager should not be content until he felt that the workpeople enjoyed their labour. It was a natural and proper thing that labour should be enjoyed, for we could not have life without labour. If this could be more realisea a great many managerial difficulties would be solved. Further, managers had a great many little matters to deal with and it was important that they should not magnify the little things. Often enough the big things were not seen much.

Mr. JoHn Cronpton moved a vote of thanks to $\mathrm{Mr}$. Arrowsmith, and said it would be a great advantage if trade union leaders would more often encourage education by pointing out to operatives that it was to their own interests to understand more thoroughly the work in which they were engaged.

In reply to Mr. Crompton, Mr. Arrowsmirh said he had lately been meeting a considerable number of trade-union leaders in reference to disputes, lists, etc., and he had found them a very advanced set of men, but they were naturally handicapped by the general outlook of their rank and file. This was the special point he wished to urge-that these men should be further educated and developed.

Col. F. R. McConNex seconded, and said that the whole subject was of the utmost interest. The fact that education was not a process of pumping in facts 
but of drawing out all that was best in the individual seomed to demand more general appreciation. In regard to the Textile Institute itself, he thought the aim should be to secure as wide a basis of membership as possible.

The Chamman supported the motion, and said that so far as ho could learn the only reason for any postponement in regard to clauses in the Fisher Bill was that this country was not yet out of a state of war.

The vote was heartily accorded, after which Col. Challoner made a plea for employment of ex-service mon.

\section{LANCASHIRE SECTION}

Meeting at Manchester, 17th January, 1921.

Mr. T. Fletcher Robinson in the Chair.

\section{THE EARLY ENGLISH COTTON INDUSTRY}

By G. W. Daniels, M.A., B. Comm.

The author prefaced this lecture by an appeal to firms who have old account books in their possession to consult the Manchester University before destroying what may prove to be valuable material for reconstructing in detail the economic history of the late 18th and the 19th centuries. He stated that our knowledge of the early history of the factory industry had been greatly increased by the action of Messrs. McConnel \& Co. in placing the records of their firm, which date back to 1793 , at the disposal of the University. The University is also indebted to Colonel Greg, of Styal, who has allowed access to valuable records of the firm with which he is connected. Mr. Daniels said that he is convinced that there is a mass of material of this kind in existence in the cotton area which would be handed over to the University for purposes of research if its value to the economic historian were realised.

The lecturer proceeded to point out how mistaken is the popular view which regards the cotton industry as a young industry, brought into existence about 1790 through the invention of the water frame and mule. It is true that the industry took on its modern form about 1790 , but the manufacture of cotton goods had been carried on in Lancashire for at least two hundred years before that date. "Cotton wool" was imported into this country long before the 16th century, and a recent discovery has established the fact that early in the 17th century the manufacture of fustiana heavy cloth made with a linen warp and cotton weft-was of considerable importance. The three main branches of the cotton industry before the introduction of machinery were fustians, checks, and smallwares, fustians being the most important. The analysis of a Manchester directory for 1772 showed that there were 55 fustian manufacturers, 45 check manufacturers, and 37 smallware manufacturers in Manchester, and in an area, bounded by Wigan, Loigh, Stockport, Oldham, and Heywood there were 77 fustian manufacturers, 26 check manufacturers, and 78 whitsters, bleachers, \&c.-figures which prove that the textile industry was flourishing long before the era of inventions.

The manufacturing process was carried on in the home or in small workshops, but Mr. Daniels emphasised the fact that the economic position of the majority of the workers was fundamentally the same as that of the operatives under the factory system. The view that under the domestic system producers were in a position of independence, in which each bought his own raw material, worked it up, and sold it, is contrary to facts. There were in country districts some semiindependent workers who divided their labour between industry and agriculture, but these were exceptions. There is a great deal of evidence that the typical town workers under the domestic system were wageearners completely dependent upon their employers, and that as far as their economic position was concerned factory organisation did not involve any change.

The lecturer mentioned several well-known Manchester families who were engaged in the cotton trade in the 16th century - the Tippings, the Mosleys, and the Cheetham brothers - and cited the methods by which Humphrey Chetham, the founder of Chetham's Hospital and Library, financed small manufacturers by selling them small quantities of cotton on long credit, or directly employed them, as typical of the business methods of a master clothier of the period.

This system of large, capitalist employers and of wage-earners was widespread a generation before the introduction of the factory system, and the disputes in the smallware and check trades, some of which ended in strikes-at least one strike, in 1750, involved thousands of workers, extended as far as Ashton and Royton, and resulted in the appearance of the leaders at the Lancashire Assizes-prove that in every essential respect the domestic system bore a strong resemblanco to the factory system .

There is no instance known of factory organisation in the cotton industry before Arkwright's experiments with roller spinning, in 1770 , although there were a considerable number of factories at work in the 'sixties at Stockport, Macclesfield, Derby, Sheffield, and London, for the manufacture of silk. Mr. Daniels considers that Arkwright's importance in the cotton industry lies not so much in his powers of inventionwhich are disputed-as in his remarkable powers as an industrial organiser. Arkwright's machinery was driven by water-power, and after the success of his enterprises many factories were erected in country districts where there was a plentiful water supply. The steam engine was first used to drive cotton spinning machinery in 1789 , and from 1790 onwards the factory system developed rapidly in the towns. This was a period when energetic men capable of adapting themselves to rapidly changing circumstances had great opportunities.

Mr. Daniols referred to a group of young Scotchmen, possessing these qualities, who came to Manchester in the 'nineties, commenced their business career with very little capital, and succeeded in building up large cotton spinning concerns. This group comprised John and James Kennedy, James McConnel, Adam and George Murray, and, eventually, the fine cotton spinning of Manchester was concentrated in their hands. The emigration from Kirkcudbright to Manchester came about through James Kennedy and James McConnel being apprenticed to William Cannon, a machine maker of Chowbent. On the conclusion of 